\title{
PENGARUH KENAIKAN PENGHASILAN TIDAK KENA PAJAK (PTKP) DAN JUMLAH WAJIB PAJAK EFEKTIF TERHADAP PENERIMAAN PPh PASAL 21
}

\author{
Nurul Susanti ${ }^{1}$ dan Andi $^{2}$ \\ 1,2Fakultas Ekonomi dan Bisnis, Universitas Sultan Ageng Tirtayasa \\ andiplg69@gmail.com
}

Diterima 05 Juli 2018, Disetujui 27 Agustus 2018

\begin{abstract}
Abstrak
Penelitian ini bertujuan untuk mengetahui kebutuhan tingkat pendapatan tidak kena pajak yang harus ditanggung termasuk jumlah wajib pajak yang efektif atas pajak penghasilan sebagaimana dimaksud dalam Pasal 21 UU No 36 Tahun 2008 memiliki potensi untuk meningkat. Penelitian ini dilakukan di KPP Pratama Serang dengan menggunakan penduduk lokal sebagai pembayar pajak yang menerima Pajak Penghasilan (PPh) berdasarkan Pasal 21 atau menggunakan sampel jenuh atau semua pajak penghasilan penduduk (PPh) sebagai responden di KPP Pratama Serang saat mengambil periode 2014 -2016. Metode yang digunakan dalam penelitian ini adalah kerja lapangan dengan mengunjungi Kota Serang sebagai Ibukota Provinsi Banten untuk melakukan survei pada penduduk lokal sebagai pembayar pajak termasuk orang-orang yang bekerja dengan status pendapatan tidak kena pajak. Hasil penelitian ini mengungkapkan bahwa jumlah pendapatan tidak kena pajak (PTKP) memiliki pengaruh yang signifikan terhadap penerimaan pajak penghasilan berdasarkan pasal 21. Selain itu, ada nilai beta negatif, yang menunjukkan bahwa tingkat Penghasilan kena pajak menambah peningkatan pajak penghasilan dari Pasal 21. Sebagaimana dicatat, jumlah pembayar pajak yang efektif secara signifikan mempengaruhi pendapatan pajak penghasilan pasal 21 dan memiliki nilai beta positif juga, menunjukkan bahwa pembayar pajak yang lebih efektif memiliki efek meningkatkan penerimaan pajak penghasilan dari pasal 21 menjadi kenyataan.
\end{abstract}

Kata Kunci : Penghasilan tidak kena pajak (PTKP), wajib pajak efektif, penerimaan pajak penghasilan $(\mathrm{PPh})$ pasal 21

\section{Abstract}

This research aims to determine the need for non-taxable income rate to be rised including the number of effective tax-payers on income tax as referred to the Article 21 of the Law No 36 of 2008 has the potential to increase. This study is conducted in KPP Pratama Serang using local population as taxpayers which accept Income Tax (PPh) based on Article 21 or using saturated sample or all population paying income tax (PPh) as respondents in KPP Pratama Serang while taking the period 2014-2016. The method used in this research is fieldwork by visiting the city of Serang as the Capital city of Banten Province to conduct a survey on local population as tax-payers including those working people with non-taxable income status. The results of this study reveal that the number of non-taxable income (PTKP) has a significant effect on the income tax revenue based on the article 21. Additionally, there is a negative beta value, which indicates that the higher rate of non-taxable income adds to an increase in the income tax of Article 21. As noted, the number of effective tax-payers significantly influence the income tax revenue of article 21 and have a positive beta value as well, indicating that the more effective tax-payers have the effect of increasing income tax revenue of the article 21 to come true.

Keywords: Non-taxable income (PTKP), tax-payers effective, income tax receipts (PPh) article 21 


\section{PENDAHULUAN}

Realisasi penerimaan Pajak Penghasilan yang diterima oleh DJP Kanwil Banten dari tahun 2014 - 2016 mengalami penurunan dari tahun 2015 sebesar Rp. 5.508.725.000,- menjadi Rp. 5.427.010.000,- pada tahun 2016. Kebijakan penyesuaian besarnya Kenaikan Penghasilan Tidak Kena Pajak (PTKP) mempertimbangkan pula kebutuhan harga pokok masyarakat, yang merupakan instrument indikator penetapan penyesuaian Upah Minimum Provinsi (UMP) atau Upah Minimum Kabupaten (UMK). Jika kenaikan UMP atau UMK tidak diimbangi dengan kenaikan PTKP maka pajak yang dibayar oleh Wajib Pajak Orang Pribadi akan semakin besar, karena jumlah penghasilan meningkat tetapi nilai PTKP tidak mengalami perubahan. Tetapi sebaliknya jika penetapan UMP atau UMK diikuti dengan kenaikan PTKP maka akan mengurangi beban pajak yang harus dibayar oleh orang pribadi sehingga dapat memiliki daya beli atau meningkatkan disposable income untuk mendorong tingkat konsumsi masyarakat yang berarti juga akan meningkatkan

Tabel 1. Penerimaan PPh Pasal 21 dan Jumlah Wajib Pajak Efektif

\begin{tabular}{cccc}
\hline \multirow{2}{*}{ Keterangan } & \multicolumn{3}{c}{ Tahun } \\
\cline { 2 - 4 } Target Penerimaan PPh 21 & Rp.428.081.208.000,- & Rp.490.886.916.000,- & Rp.607.236.103.000,- \\
\hline Realisasi Peneriman PPh 21 & Rp 485.196.033.250,- & Rp530.790.261.367,- & Rp. 473.271.413.085,- \\
\hline Jumlah Wajib Pajak Efektif & 235.531 jiwa & 286.826 jiwa & 312.581 jiwa \\
\hline
\end{tabular}

Sumber : KPP Pratama Serang (2018)

Dalam meningkatkan penerimaan pajak, Wajib Pajak merupakan salah satu aspek penting dan merupakan tulang punggung penerimaan pajak, semua kegiatan Wajb Pajak dalam menjalankan kewajiban perpajakanya telah diatur dalam Ketentuan Umum dan Tata Cara Perpajakan (KUP), hal tersebut tentunya sebagai upaya dari Direktorat Jendral Pajak untuk memberikan pemahaman kepada masyarakat pada umumnya dan Wajib Pajak pada khusunya tentang pajak dan betapa pentingnya pajak bagi suatu negara dan juga semua masyarakatnya, atas hal tersebutlah diharapkan masyarakat sadar akan pajak (Fermana,2013).

Penelitian ini merupakan ekstensi replikasi atau bisa disebut juga dengan replikasi pengembangan dari penelitian yang telah dilakukan Juariah,Siti (2017) dan Rahmawati,Lusy (2016) menjadi pengaruh kenaikan Penghasilan Tidak Kena Pajak (PTKP) dan jumlah Wajib Pajak efektif terhadap penerimaan basis objek Pajak Pertambahan Nilai (PPN) lebih lanjut juga akan berpotensi terhadap peningkatan Pajak Penghasilan Badan (Apriliawati, Setiawan 2017).

Kenaikan Upah minimum Kabupaten/Kota (UMK) yang berlaku di kabupaten dan kota Serang dari tahun 2014-2016. Untuk seluruh Wajib Pajak PPh Pasal 21 yang menerima gaji sesuai dengan UMK yang berlaku dikenakan PTKP, karena tarif yang berlaku pada tahun 2014 sebesar Rp.24.300.000,-/thn atau Rp.2.025.000,-/bln. Selanjutnya di tahun 2015 dan 2016 gaji yang sesuai dengan UMK pada Kabupaten dan Kota Serang dibawah dari tarif PTKP yang berlaku, pada tahun 2015 tarif PTKP sebesar Rp.34.000.000,- dalam setahun atau Rp.2.833.333,- untuk setiap bulanya dan ditahun 2016 tarif PTKP yang berlaku sebesar Rp.54.000.000,- setiap tahun atau Rp.4.500.000,untuk setiap bulanya. Hal ini besar kemungkinan akan berdampak pada penerimaan Pajak Penghasilan Pasal 21 di KPP Pratama Serang yang akan menurun dari tahun sebelumnya, seperti yang dapat kita lihat dari tabel sebagai berikut:
Pajak Penghasilan PPh Pasal 21. Hal ini dilakukan karena terdapat fenomena yang menarik untuk diteliti dalam hal terkait kenaikan Penghasilan Tidak Kena Pajak (PTKP), Jumlah Wajib Pajak Efektif, dan Penerimaan Pajak Penghasilan Pasal 21.

Berdasarkan hasil penelitian yang dilakukan oleh Andiyanto, Dimas dan Malia,Qoyyimah menyatakan bahwa pengaruh penerapan kenaikan penghasilan tidak kena pajak (PTKP) terhadap penerimaan PPh pasal 21 orang pribadi terdapat hasil yang berbeda. Andiyanto,Dimas (2014) melakukan penelitian pada dua KPP dan mendapatkan hasil yang berbeda, pada KPP Malang Selatan menghasilkan penurunan realisasi penerimaan PPh pasal 21 dan pada KPP Pratama Banyuwangi tidak mengakibatkan penurunan realisasi penerimaan PPh pasal 21. Kemudian penelitian yang dilakukan oleh Malia,Qoyyimah (2016) menyatakan untuk tahun 2013 tidak mampu meningkatkan penerimaan pajak, 
namun pada tahun berikutnya 2014-2015 mampu meningkatkan penerimaan pajak. Untuk penelitian terdahulu mengenai Wajib Pajak efektif berdasarkan hasil penelitian dari Rahmawati,Lusy (2016) menghasilkan bahwa secara parsial jumlah Wajib Pajak Efektif berpengaruh signifikan terhadap penerimaan pajak dan dapat dikatakan bahwa jumlah Wajib Pajak Efektif berbanding searah dengan penerimaan Pajak yang dilaporkan.

Penelitian ini memiliki perbedaan dengan peneliti sebelumnya, penelitian yang dilakukan oleh Juariah,Sitti dimana pada penelitian terdahulu sampel penelitiannya adalah Pengaruh Jumlah Wajib Pajak dan Batas Kenaikan Penghasilan Tidak Kena Pajak terhadap penerimaan pajak penghasilan orang pribadi periode 2011 sampai 2015, sedangkan pada penelitian ini sampelnya adalah pengaruh kenaikan penghasilan tidak kena pajak (PTKP) terhadap penerimaan Pajak Penghasilan Pasal 21 pada KPP Pratama Serang, kemudian untuk variabel jumlah Wajib Pajak Efektif melihat referensi dari penelitian yang dilakukan oleh Rahmawati,Lusy (2016) yang berjudul Pengaruh Jumlah Wajib Pajak Efektif dan Penagihan dengan Surat Paksa terhadap penerimaan pajak pada KPP Pratama Purwakarta dari tahun 2011-2015, untuk penagihan dengan surat paksa dalam penelitian ini tidak digunakan karena dalam penelitian ini berfokus pada Wajib Pajak PPh 21 karyawan yang pada dasarnya system pemungutan pajaknya menggunakan withholding system kecil kemungkinan untuk dilakukan penagihan melalui surat paksa.

Berdasarkan pemasalahan yang diuraikan diatas, maka yang menjadi rumusan masalah dalam penelitian ini adalah: 1) Apakah terdapat pengaruh Penghasilan Tidak Kena Pajak terhadap penerimaan Pajak Penghasilan (PPh) Pasal 21 di KPP Pratama Serang; 2)Apakah terdapat pengaruh jumlah Wajib
Pajak Efektif terhadap penerimaan Pajak Penghasilan (PPh) Pasal 21 di KPP Pratama Serang.

\section{TINJAUAN PUSTAKA}

Menurut Resmi,Siti (2013:96) penghasilan tidak kena pajak (PTKP) merupakan jumlah penghasilan tertentu yang tidak kena pajak. Untuk menghitung besarnya Penghasilan Kena Pajak Wajib Pajak dalam negeri, penghasilan netonya dikurangi dengan jumlah Penghasilan Tidak Kena Pajak. Pada prinsipnya biaya yang boleh dikurangkan dari penghasilan bruto adalah biaya yang mempunyai hubungan langsung dan tidak langsung dengan usaha atau kegiatan untuk mendapatkan, menagih, dan memelihara penghasilan yang merupakan objek pajak yang pembebanannya dapat dilakukan dalam tahun pengeluaran atau selama masa manfaat dari pengeluaran tersebut.

Undang-Undang Pajak Penghasilan Nomor 36 Tahun 2008 menerapkan PTKP terbaru yang mulai berlaku sejak 1 Januari 2009, dan pada tahun 2012 telah muncul Peraturan Menteri Keuangan Nomor 162/PMK.011/2012 yang menerapkan PTKP terbaru, kemudian disusul di tahun 2015 dikeluarkan Peraturan Menteri Keuangan Nomor 122/PMK.010/ 2015, dan terakhir pada tahun 2016 ini pemerintah kembali mengoreksi besarnya PTKP dengan dikeluarkannya Peraturan Menteri Keuangan Nomor 101/PMK.010/2016. Jadi selama 7 Tahun saja PTKP sudah diubah sebanyak empat kali. Perubahan terbaru yang kembali dilakukan oleh pemerintah dengan dilakukanya Peraturan Menteri Keuangan PMK No.101/PMK.010/2016 Pada tanggal 22 Juni 2016 berlaku sejak 1 Januari 2016 yaitu besarnya Penghasilan Tidak Kena Pajak (PTKP) sampai dengan tahun 2017 adalah Rp 54.000.000,-, sebagai berikut:

Tabel 2. PTKP tahun 2016-2017

\begin{tabular}{lccccc}
\hline \multicolumn{2}{c}{ PTKP Pria/Wanita Lajang } & & PTKP Pria Kawin & \multicolumn{2}{c}{ PTKP Suami Istri Gabung } \\
\hline TK/0 & Rp54.000.000,- & K/0 & Rp58.500.000,- & K/I/0 & Rp112.500.000,- \\
\hline TK/1 & Rp58.500.000,- & K/1 & Rp63.000.000,- & K/I/1 & Rp117.000.000,- \\
\hline TK/2 & Rp63.000.000,- & K/2 & Rp67.500.000,- & K/I/2 & Rp121.500.000,- \\
\hline TK/3 & Rp67.500.000,- & K/3 & Rp72.000.000,-- & K/I/3 & Rp126.000.000,- \\
\hline
\end{tabular}

Sumber : PMK No. 101/PMK.010/2016 (pajak.go.id)

Usulan kenaikan Penghasilan Tidak Kena Pajak (PTKP) Tahun 2016 untuk Wajib Pajak yang semula Rp.36.000.000,- berubah menjadi Rp.54.000.000,pertahun (setara dengan Rp. 4.500.000,- per bulan) telah disetujui DPR. Jika dianalisa kenaikan PTKP 2016 ini lebih kurang 50\% dari PTKP 2015, dan kenaikan PTKP 2015 juga demikian lebih kurang 50\% dari PTKP 2014. Dengan adanya penyesuaian batasan PTKP, harapan pemerintah adalah kenaikan ini dapat memberikan efek baik untuk pertumbuhan, sehingga konsumsi rumah tangga bisa semakin besar dan investasi juga besar sehingga daya beli masyarakat 
juga semakin besar (Handoko,2016).

Berdasarkan teori dan penjelasan diatas indikator pada variabel Penghasilan Tidak Kena Pajak adalah besarnya tarif Penghasilan Tidak Kena Pajak berdasarkan peraturan dari pemerintah dan dalam penelitian ini menggunakan tahun 2014-2016.

\section{Wajib Pajak Efektif dan Non Efektif}

Berdasarkan Surat Edaran Dirjen Pajak Nomor SE-26/PJ.2/1988 yang telah diperbaharui dengan Surat Edaran Dijen Pajak Nomor SE-89/PJ/2009 Wajib Pajak efektif dan Wajib Pajak non efektif dengan pengertian sebagai berikut: 1) Wajib pajak efektif adalah wajib pajak yang memenuhi kewajiban perpajakannya berupa memenuhi kewajiban menyampaikan Surat Pemberitahuan (SPT) Masa dan atau Surat Pemberitahuan (SPT) Tahunan sebagaimana mestinya; 2) Wajib pajak non efektif adalah Wajib Pajak yang tidak melakukan pemenuhan kewajiban perpajakannya baik berupa pembayaran maupun penyampaian SPT Masa dan atau SPT Tahunan sesuai dengan ketentuan Peraturan Perundang-Undangan Perpajakan yang nantinya dapat diaktifkan kembali. Sebagaimana telah ditegaskan dalam surat edaran Direktorat Jendral Pajak Nomor SE-89/PJ/2009, wajib pajak non efektif sebagai berikut: a) Selama tiga tahun berturut-turut tidak pernah melakukan pemenuhan kewajiban perpajakan baik berupa pembayaran pajak maupun penyampaian SPT Masa dan atau SPT Tahunan; b) Wajib pajak yang sudah meninggal dunia/bubar tetapi belum ada surat keterangan resminya; c) Tidak diketahui atau ditemukan lagi alamatnya; d) Wajib pajak secara nyata tidak menunjukan kegiatan usahanya.

Indikator yang digunakan dalam variabel ini yaitu banyaknya Wajib Pajak Orang Pribadi Karyawan (PPh Pasal 21) yang efektif bayar pada KPP Pratama Serang dari tahun 2014-2016.

Wajib Pajak pribadi adalah setiap orang pribadi yang memiliki penghasilan di atas pendapatan tidak kena pajak. Wajib pajak meliputi pembayaran pajak, pemotong pajak, dan pemungut pajak yang mempunyai hak dan kewajiban perpajakan yang sesuai dengan Undang-Undang Nomor 28 Tahun 2007 tentang Ketentuan Umum dan Tata Cara Perpajakan. Wajib Pajak Orang Pribadi menurut Suandy,Erly (2016:105) yaitu Orang Pribadi menurut ketentuan peraturan perundang-undangan perpajakan ditentukan untuk melakukan kewajiban perpajakan termasuk pemungut pajak atau pemotong pajak tertentu.

Menurut Mardiasmo (2013:135), pajak pengha- silan adalah pajak yang dikenakan terhadap subjek pajak atau penghasilan yang diterima atau diperoleh dalam satu tahun pajak. Undang-Undang Pajak Penghasilan ( $\mathrm{PPh}$ ) mengatur pengenaan pajak penghasilan terhadap subjek pajak berkenaan dengan penghasilan yang diterima atau diperolehnya dalam tahun pajak. Subjek pajak tersebut dikenai pajak apabila menerima atau memperoleh penghasilan. Subjek pajak yang menerima atau memperoleh penghasilan, dalam Undang - Undang PPh disebut Wajib Pajak.

Menurut PER-31/PJ/2012 Pasal 1 ayat 2 Pajak Penghasilan (PPh) Pasal 21 adalah pungutan resmi yang ditujukan kepada masyarakat atas penghasilan berupa gaji, upah, honor, tunjangan, serta pembayaran lain dengan nama dan dalam bentuk apapun sehubungan dengan pekerjaan atau jabatan, jasa dan kegiatan yang dilakukan oleh orang pribadi Subjek Pajak dalam negeri, sebagaimana dimaksud dalam Undang-Undang Nomor 36 Tahun 2008 tentang Pajak Penghasilan. Berikut tarif PPh Pasal 21 yang dikenakan atas Orang Pribadi, sehingga besarnya tarif PPh Pasal 21 yang digunakan terdiri dari: a) Sampai dengan Rp 50.000.000,- (5\%); b) Diatas Rp 50.000.000 s/d Rp 250.000.000,- (15\%); c) Diatas Rp 250.000.000 s/d Rp 500.000.000,- (25\%); d) Diatas Rp 500.000.000,- (30\%).

Pemotong Pajak Penghasilan Pasal 21 merupakan pihak yang berkewajiban memotong pajak atas penghasilan yang dibayarkan dan menyetorkan Pajak Penghasilan Pasal 21 yang dipotong ke kas negara paling lambat tanggal 10 bulan berikutnya setelah hutang pajak. Menurut Mardiasmo (2013:170) para pemotong Pajak Penghasilan Pasal 21, yang selanjutnya disingkat Pemotong Pajak adalah: 1) Pemberi kerja yang terdiri dari orang pibadi dan badan, baik merupakan pusat maupun cabang, perwakilan atau unit, bentuk usaha tetap, yang membayar gaji, upah, honorarium, tunjangan, dan pembayaran lain dengan nama apapun, sebagai imbalan sehubungan dengan pekerjaan atau jasa yang dilakukan oleh pegawai/ bukan pegawai; 2) Bendaharawan pemerintah termasuk bendaharawan pada Pemerintah Pusat/ Daerah, instansi atau lembaga pemerintah, lembaga-lembaga negara lainnya, dan Kedutaan Besar Republik Indonesia di luar negeri yang membayarkan gaji, upah, honorarium, tunjangan, dan pembayaran lain dengan nama apapun sehubungan dengan pekerjaan atau jabatan, jasa, dan kegiatan; 3) Dana pensiun, badan penyelenggara Jaminan Sosial Tenaga Kerja, dan badan-badan lain yang membayar uang pension serta Tabungan Hari Tua/Jaminan Hari Tua; 4) Peru- 
sahaan, badan, dan bentuk usaha tetap, yang membayar honorarium/pembayaran lain sebagai imbalan sehubungan dengan kegiatan, jasa, termasuk jasa tenaga ahli dengan status Wajib Pajak dalam negeri yang melakukan pekerjaan bebas dan bertindak untuk dan atas namanya sendiri, bukan untuk dan atas nama persekutuannya; 5) Yayasan (termasuk yayasan di bidang kesejahteraan, rumah sakit, pendidikan, kesenian, olah raga, kebudayaan), lembaga, kepanitiaan, asosiasi, perkumpulan, organisasi massa, organisasi sosial politik, dan organisasi lainnya dalam bentuk apapun di segala bidang kegiatan sebagai pembayar gaji, upah, honorarium, atau imbalan dengan nama apapun sehubungan dengan pekerjaan, jasa, kegiatan yang dilakukan oleh orang pribadi; 6) Perusahaan, badan, dan bentuk usaha tetap, yang membayarkan honorarium/imbalan lain kepada peserta pendidikan, pelatihan, dan pemagangan; 7) Penyelenggara kegiatan (termasuk badan pemerintah, organisasi internasional, perkumpulan, orang pribadi, serta lembaga lainnya yang menyelenggarakan kegiatan) yang membayar honorarium, hadiah, atau penghargaan dalam bentuk apapun kepada Wajib Pajak orang pribadi dalam negeri berkenaan dengan sesuatu kegiatan.

Penghasilan yang dipotong PPh Pasal 21 (Resmi,Siti 2013:171) yaitu: 1) Penghasilan yang diterima atau diperoleh pegawai tetap, baik berupa penghasilan yang bersifat teratur maupun tidak teratur; 2) Penghasilan yang diterima atau diperoleh penerima pensius secara teratur berupa uang pensiun atau penghasilan sejenisnya; 3) Penghasilan sehubungan dengan pemutusan hubungan kerja dan penghasilan sehubungan dengan pensiun yang diterima secara sekaligus berupa uang pesangon, uang manfaat pensiun, tunjangan hari tua atau jaminan hari tua, dan pembayaran lain sejenis; 4) Penghasilan pegawai tidak tetap atau tenaga kerja lepas, berupa upah harian, upah mingguan, upah satuan, upah borongan atau upah yang dibayarkan bulanan; 5) Imbalan kepada bukan pegawai, antara lain berupa honorarium, komisi, fee, dan imbalan sehubungan dengan pekerjaan, jasa, dan kegiatan yang dilakukan; 6) Imbalan kepada peserta kegiatan, antara lain berupa uang saku, uang representasi, uang rapat, honorarium, hadiah atau penghargaan dengan nama dan dalam bentuk apapun, dan imbalan sejenis dengan nama apa pun.

Penghasilan yang tidak dipotong PPh Pasal 21 adalah: 1) Pembayaran asuransi dari perusahaan asuransi kesehatan, asuransi kecelakaan, asuransi jiwa, asuransi dwiguna, dan asuransi bea siswa; 2)
Penerimaan dalam bentuk natura dan kenikmatan dalam bentuk apapun yang diberikan oleh Wajib Pajak atau Pemerintah, kecuali diberikan oleh bukan Wajib Pajak selain Pemerintah, atau Wajib Pajak yang dikenakan Pajak Penghasilan yang bersifat final dan yang dikenakan Pajak Penghasilan berdasarkan norma penghitungan khusus; 3) Iuran pensiun yang dibayarkan kepada dana pensiun yang pendiriannya telah disahkan oleh Menteri Keuangan dan iuran Jaminan Hari Tua kepada badan penyelenggara Jamsostek yang dibayar oleh pemberi kerja; 4) Zakat yang diterima oleh orang pribadi yang berhak dari badan atau lembaga amil zakat yang dibentuk atau disahkan oleh Pemerintah; 5) Beasiswa yang memenuhi persyaratan tertentu (Pasal 3 ayat 1 Undang-Undang $\mathrm{PPh}$ ). Ketentuannya di atur lebih lanjut dalam Peraturan Menteri Keuangan No. 246/ PMK.03/2008.

Peghasilan pegawai tetap berdasarkan periode diterimanya penghasian yaitu: 1) Penghasilan Teratur. Penghasilan Pegawai Tetap yang bersifat Teratur adalah penghasilan bagi pegawai tetap berupa gaji atau upah, segala macam tunjangan, dan imbalan dengan nama apapun yang diberikan secara periodik berdasarkan ketentuan yang ditetapkan oleh pemberi kerja, termasuk uang lembur; 2) Penghasilan Tidak Teratur. Penghasilan Pegawai Tetap yang bersifat Tidak Teratur adalah penghasilan bagi pegawai tetap selain penghasilan yang bersifat teratur, yang diterima sekali dalam satu tahun atau periode lainnya, antara lain berupa bonus, tunjangan hari raya (THR), jasa produksi, gratifikasi, atau imbalan sejenis lainnya dengan nama apapun.

Pengenaan atas pajak penghasilan teratur dilakukan dengan melakukan perhitungan atas: a) Penghasilan Bruto. Penghasilan bruto pegawai tetap merupakan jumlah dari gaji pokok beserta dengan tunjangan. Berbagai macam tunjangan yang perhitungan $\mathrm{PPh}$ Pasal 21 digabung dengan gaji bulanan seperti : uang sokongan, uang tunggu, uang ganti rugi, tunjangan istri, tunjangan anak, tunjangan jabatan, tunjangan khusus, tunjangan transport, tunjangan pajak, tunjangan iuran pensiun, tunjangan pendidikan anak, tunjangan premi asuransi yang dibayar pemberi kerja, dan lain sebagainya; b) Penghasilan Netto. Besarnya penghasilan netto pegawai tetap ditentukan berdasarkan penghasilan bruto penghasilan dikurangi dengan: 1) Biaya Jabatan adalah biaya untuk mendapatkan, menagih dan memelihara penghasilan yang dapat dikurangkan dari penghasilan setiap orang yang bekerja sebagai pegawai tetap tanpa memandang jabatan atau tidak, besarnya jabatan yang ditetapkan yaitu 5\% dari 
penghasilan bruto, dan maksimum adalah Rp 6.000.000,- setahun atau Rp 500.000,- perbulan; 2) Iuran yang terkait dengan gaji yang dibayar oleh pegawai kepada dana pensiun yang pendiriannya telah disahkan oleh Menteri Keuangan atau badan penyelenggara Tabungan Hari Tua (THT) atau Jaminan Hari Tua yang dipersamakan dengan dana pensiun; 3) Pengurangan berupa biaya jabatan dan iuran pensiun serta iuran THT tidak berlaku pada penghasilan-penghasilan seperti berikut: a) Upah harian, upah mingguan, upah satuan, dan upah borongan; $b$; Uang tebusan pensiun, uang pesangon, uang Tabungan Hari Tua atau Jaminan Hari Tua, dan pembayaran lain yang sejenis; c) Honorarium, uang saku, hadiah, atau penghargaan dengan nama dalam bentuk apapun, komisi, beasiswa, dan pembayaran lain sebagai imbalan sehubungan dengan pekerjaan, jasa dan kegiatan oleh wajib pajak dalam negeri.
Pengertian penerimaan pajak adalah semua penerimaan negara yang terdiri atas pajak dalam negeri dan pajak perdagangan internasional. Penerimaan negara Indonesia sebagian besar berasal dari pajak, tetapi upaya mengumpulkan dana dari pajak bukan berarti harus semaksimal mungkin. Hal ini bertentangan dengan hak warga negara untuk tetap dapat menjalankan kehidupannya yang layak. Tetapi pengumpulan dana dari pajak diharapkan adalah seoptimal mungkin, karena memasukan dana secara optimal bukan berarti memasukan dana secara maksimal, atau sebesar-besarnya, tetapi usaha memasukan dana jangan sampai ada yang terlewatkan, baik subjek pajaknya maupun objek pajaknya (Lainutu, 2013). Indikator dalam variabel Penerimaan Pajak Penghasilan Pasal 21yaitu realisasi penerimaan pajak penghasilan pasal 21 setiap bulan untuk periode 2014 sampai 2016 pada KPP Pratama Serang.

Tabel 3. Penelitian Terdahulu

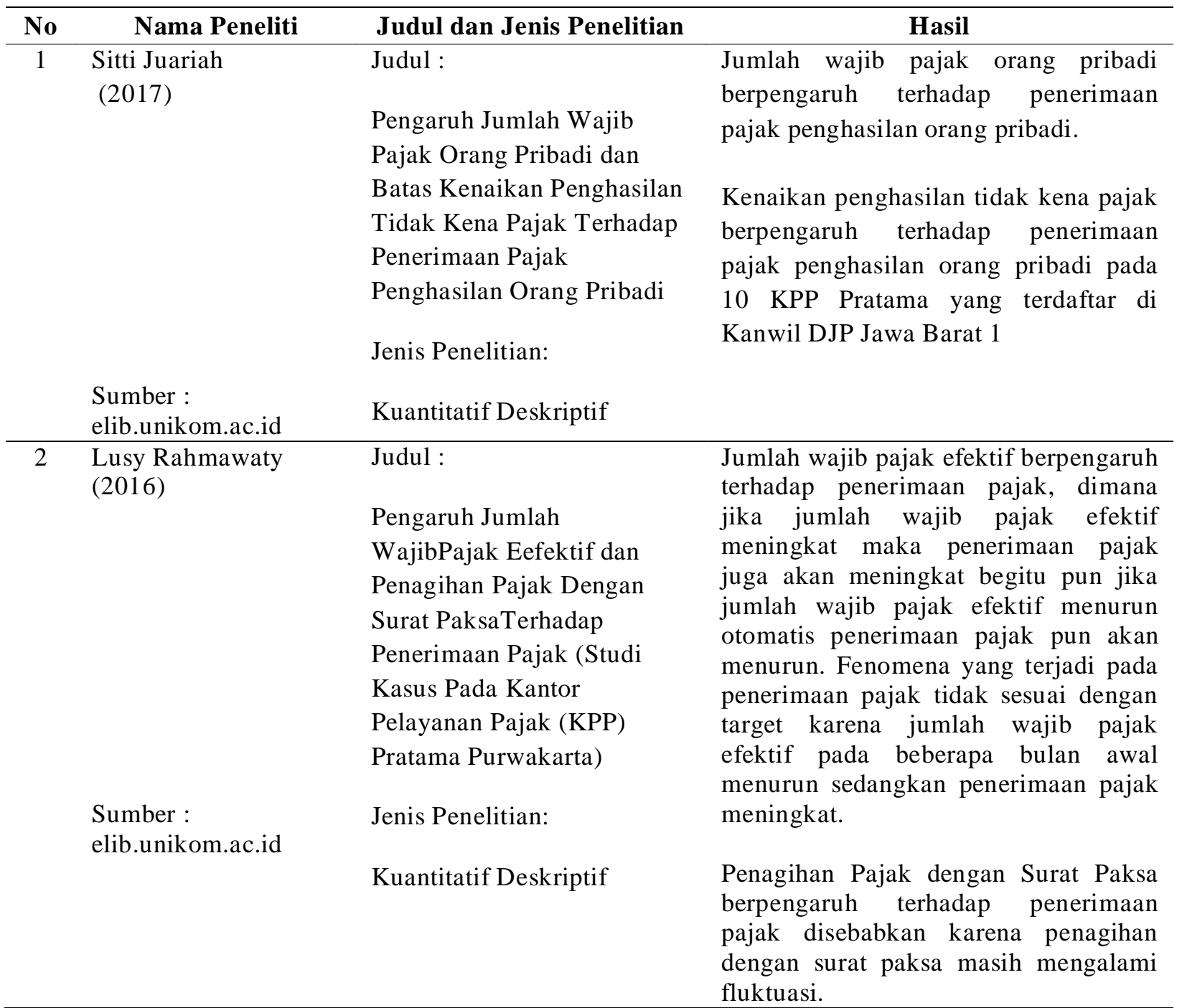

Sumber : Siiti Juariah (2017), Lusy Rahawati (2016), Nuritomo (2008), Lainutu (2013) 
Lanjutan Tabel 3. Penelitian Terdahulu

\begin{tabular}{|c|c|c|c|}
\hline No & Nama Peneliti & Judul dan Jenis Penelitian & Hasil \\
\hline 3 & $\begin{array}{l}\text { Sumber: Jurnal Ilmiah } \\
\text { A kuntansi dan Bisnis } \\
\text { Vol. 6, No. } 1 \text { Januari } \\
2011\end{array}$ & $\begin{array}{l}\text { Judul : } \\
\text { Pengaruh Peningkatan } \\
\text { Penghasilan Tidak Kena } \\
\text { Pajak (PTKP) Terhadap } \\
\text { Penerimaan Pajak Studi } \\
\text { Pada KPP Yogyakarta Satu }\end{array}$ & $\begin{array}{l}\text { Penerimaan pajak KPP Yogyakarta } \\
\text { Satu mengalami penurunan pada tahun } \\
2005 \text {. Pada tahun } 2005 \text { pajak } \\
\text { penghasilan yang diterima KPP } \\
\text { Yogyakarta Satu mengalami penurunan } \\
\text { sebesar 5,36 persen atau senilai Rp. } \\
\text { 7.337.261.240.000 dengan pos pajak } \\
\text { penghasilan pasal } 21 \text { menumbang } \\
\text { penurunan terbesar, yaitu sebesar } 26,04 \\
\text { persen. Hal ini disebabkan oleh } \\
\text { beberapa faktor antara lain, perubahan } \\
\text { kebijakan yang memisahkan kantor } \\
\text { pelayanan pajak Yogyakarta menjadi } \\
\text { dua tempat dan adanya kebijakan } \\
\text { pemerintah tentang peningkatan } \\
\text { penghasilan tidak kena pajak yang } \\
\text { diresmikan melalui peraturan menteri } \\
\text { keuangan nomor } 564 / K M K .03 / 2004\end{array}$ \\
\hline 4 & Amina Lainutu (2013) & $\begin{array}{l}\text { Pengaruh Jumlah Wajib } \\
\text { Pajak PPH } 21 \text { Terhadap } \\
\text { Penerimaan PPH } 21 \\
\text { Pada KPP Pratama Manado }\end{array}$ & $\begin{array}{l}\text { Berdasarkan hasil analisa } \\
\text { menunjukkan bahwa jumlah Wajib } \\
\text { Pajak PPh Pasal 21 Orang Pribadi } \\
\text { mempunyai keeratan hubungan yang } \\
\text { cukup kuat terhadap penerimaan PPh } \\
\text { Pasal 21, yaitu sebesar 0,573, } \\
\text { sedangkan untuk sifat korelasinya } \\
\text { adalah positif }(+) .\end{array}$ \\
\hline & $\begin{array}{l}\text { Sumber: } \\
\text { Jurnal EMBA } \\
\text { Volume.1 No.3 }\end{array}$ & $\begin{array}{l}\text { Jenis Penelitian: } \\
\text { Kuantitatif Deskriptif }\end{array}$ & $\begin{array}{l}\text { Berdasarkan hasil perhitungan nilai } \\
\text { koefisien determinasi (R2) dalam } \\
\text { analisis regresi menunjukkan bahwa } \\
\text { variabel jumlah Wajib Pajak PPh } 21 \\
\text { Orang Pribadi yang terdaftar mampu } \\
\text { menjelaskan } 32,8 \% \text { variasi jumlah } \\
\text { penerimaan pajak PPh Pasal 21, } \\
\text { sedangkan } 67,2 \% \text { lainnya menujukkan } \\
\text { bahwa variasi jumlah penerimaan pajak } \\
\text { PPh Pasal } 21 \text { dijelaskan oleh variabel } \\
\text { lain. }\end{array}$ \\
\hline
\end{tabular}

Sumber : Siti Juariah(2017) Lusy Rahawati(2016) Nuritomo (2008) Lainutu(2013)

\section{Hipotesis}

Berdasarkan uraian diatas, maka hipotesis untuk penelitian ini adalah:

$\mathrm{H}_{1}$ : Kenaikan Penghasilan Tidak Kena Pajak (PTKP) berpengaruh terhadap penerimaan
Pajak Penghasilan (PPh) Pasal 21.

$\mathrm{H}_{2}$ : Jumlah Wajib Pajak Efektif berpengaruh terhadap Penerimaan Pajak Penghasilan Orang Pribadi.

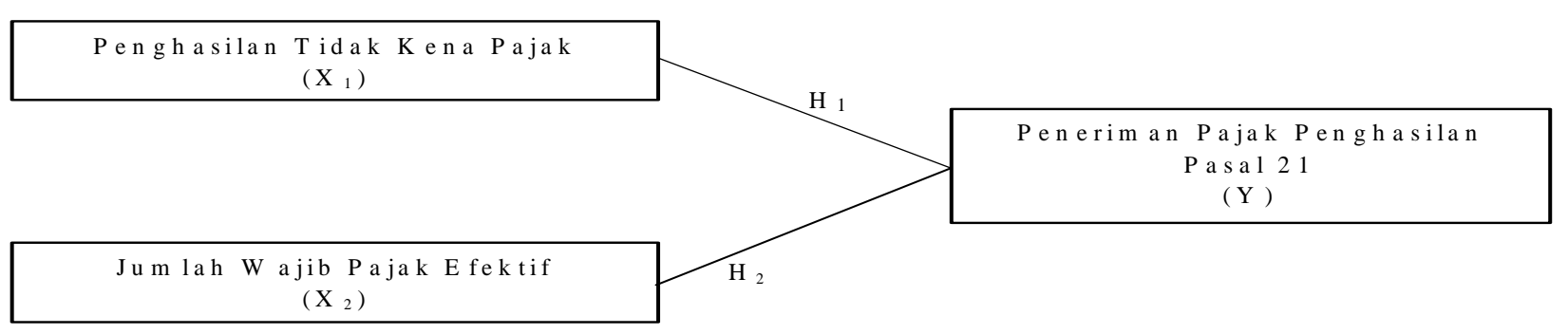

Sumber : Peneliti, (2018)

Gambar 1. Model Penelitian 


\section{METODE}

Penelitian ini merupakan penelitian kuantitatif yang menguji hubungan kausalitas (sebab-akibat) antara X1, X2 dan Y. Pengujian hipotesis dalam penelitian di analisis dengan alat bantu Statistical Product and Service Solutions (SPSS) versi 20. Populasi dalam penelitian ini adalah Penerimaan Pajak Penghasilan (PPh) Pasal 21 pada Kantor Pelayanan Pajak Pratama Serang. Penelitian ini menggunakan sampel jenuh atau semua populasi digunakan sebagai sampel yaitu penerimaan Pajak
Penghasilan (PPh) Pasal 21 di KPP Pratama Serang setiap bulan untuk periode 2014 sampai 2016. Teknik dalam penelitian ini adalah penelitian dengan mengumpulkan data-data sekunder. Data sekunder yang digunakan dalam penelitian ini adalah jumlah Wajib Pajak Efektif, realisasi penerimaan Pajak Penghasilan Pasal 21, dan target penerimaan Pajak Penghasilan Pasal 21. Data tersebut di peroleh KPP Pratama Serang setiap bulanya dari tahun 2014-2016. Untuk itu penelitian ini melakukan 2 metode dalam pengumpulan data, yaitu: 1) Observasi Langsung dan 2) Studi Kepustakaan (library research).

Tabel 4. Operasionalisasi Variabel

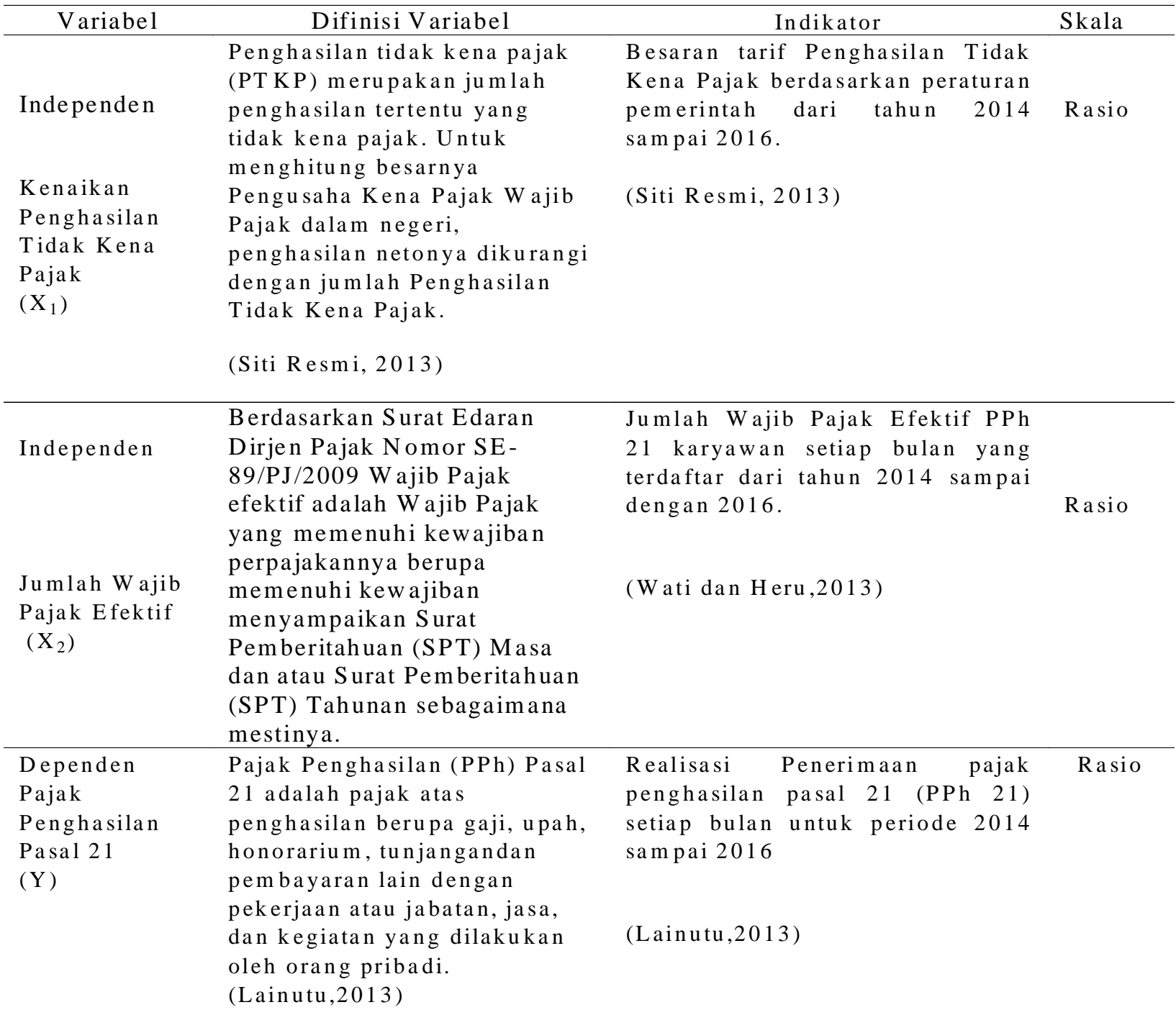

Sumber : Sitti Juariah (2017) Lusy Rahmawati (2016) Lainutu(2013)

Satatistik deksriptif digunakan untuk memberikan deskripsi suatu data yang dilihat dari rata-rata (mean), standar deviasi (standard deviation) dan maksimum-minimum. Ada beberapa pengujian yang harus dijalankan terlebih dahulu untuk menguji apakah model yang dipergunakan tersebut mewakili atau mendekati kenyataan yang ada. Untuk menguji kelayakan model regresi yang digunakan, maka harus terlebih dahulu memenuhi uji asumsi klasik yang terdiri dari : Uji Normalitas, Uji Multikolonieritas, Uji Heteroskedastisitas, dan Uji Autokorelasi.

Analisis Regresi linier berganda merupakan 
analisis yang mengukur pengaruh variabel bebas terhadap variabel terikat. Pengukuran pengaruh ini melibatkan beberapa variabel bebas (X) dan variabel terikat $(\mathrm{Y})$. Adapun rumus analisis regresi linier berganda yang digunakan dalam penelitian ii sebagai berikut:

$$
\mathbf{Y}=\alpha+\beta_{1} X_{1}+\beta_{2} X_{2}+
$$

Ketetapan fungsi regresi sampel dalam menaksir nilai aktual dapat diukur dari Goodness of Fit nya. Secara statistik, setidaknya ini dapat diukur dari nilainilai koefisien determinasi dan nilai statistik F. Perhitungam statistik disebut signifikan secara statistik apabila nilai uji statistiknya berada dalam daerah kritis (daerah dimana Ho ditolak). Sebaliknya disebut tidak signifikan bila nilai uji statistiknya berada dalam daerah dimana Ho diterima (Ghozali,2013:97). Koefisien determinasi (R2) pada intinya mengukur seberapa jauh kemampuan model dalam menerangkan variasi variabel independen (Ghazali,2013:97). Nilai adjusted R2 yang mendekati satu berarti kemampuan variabel-variabel independen memberikan hampir semua informasi yang dibutuhkan untuk memprediksi variasi variabel independen. Nilai adjusted $R 2$ yang kecil atau di bawah 0,5 berarti kemampuan variabel-variabel independen dalam menjelaskan variabel dependen sangat terbatas. Nilai yang mendekati satu berarti variabel-variabel independen memberikan hampir semua informasi yang dibutuhkan untuk memprediksi variasi variabel dependen.

Pengujian hipotesis pada penelitian ini menggunakan model analisis regresi linier berganda dan uji t (t-test). Uji signifikansi secara parsial atau sering kali disebut uji t digunakan untuk melihat pengaruh variabel-variabel independen secara individu terhadap variabel dependen (Ghazali,2013:101). Dasar pengambilan keputusan dalam uji t sebagai berikut: a) Jika nilai signifikansi t $<0,05$ maka hipotesis diterima. Ini berarti bahwa secara parsial variabel independen tersebut mepunyai pengaruh yang signifikan terhadap variabel dependen; b) Jika nilai signifikansi t $>0,05$ maka hipotesis ditolak. Ini berarti bahwa secara parsial variabel independen tersebut tidak mempunyai pengaruh yang signifikan terhadap variabel dependen.

Uji t dapat pula dilihat dengan cara sebagai berikut: a) Jika $\mathrm{t}$ hitung $>\mathrm{t}$ tabel, maka hipotesis diterima. Ini berarti bahwa secara parsial variabel independen tersebut mempunyai pengaruh terhadap variabel dependen; b) Jika $\mathrm{t}$ hitung $<\mathrm{t}$ tabel, maka hipotesis ditolak. Ini berarti bahwa secara parsial variael independen tersebut tidak mempunyai pengaruh terhadap variabel dependen.

\section{HASIL DAN PEMBAHASAN}

Berdasarkan gambar 2 menunjukkan kenaikan tarif Penghasilan Tidak Kena Pajak (PTKP) yang terjadi pada tahun 2014-2016, sebagi berikut:

$\varepsilon$

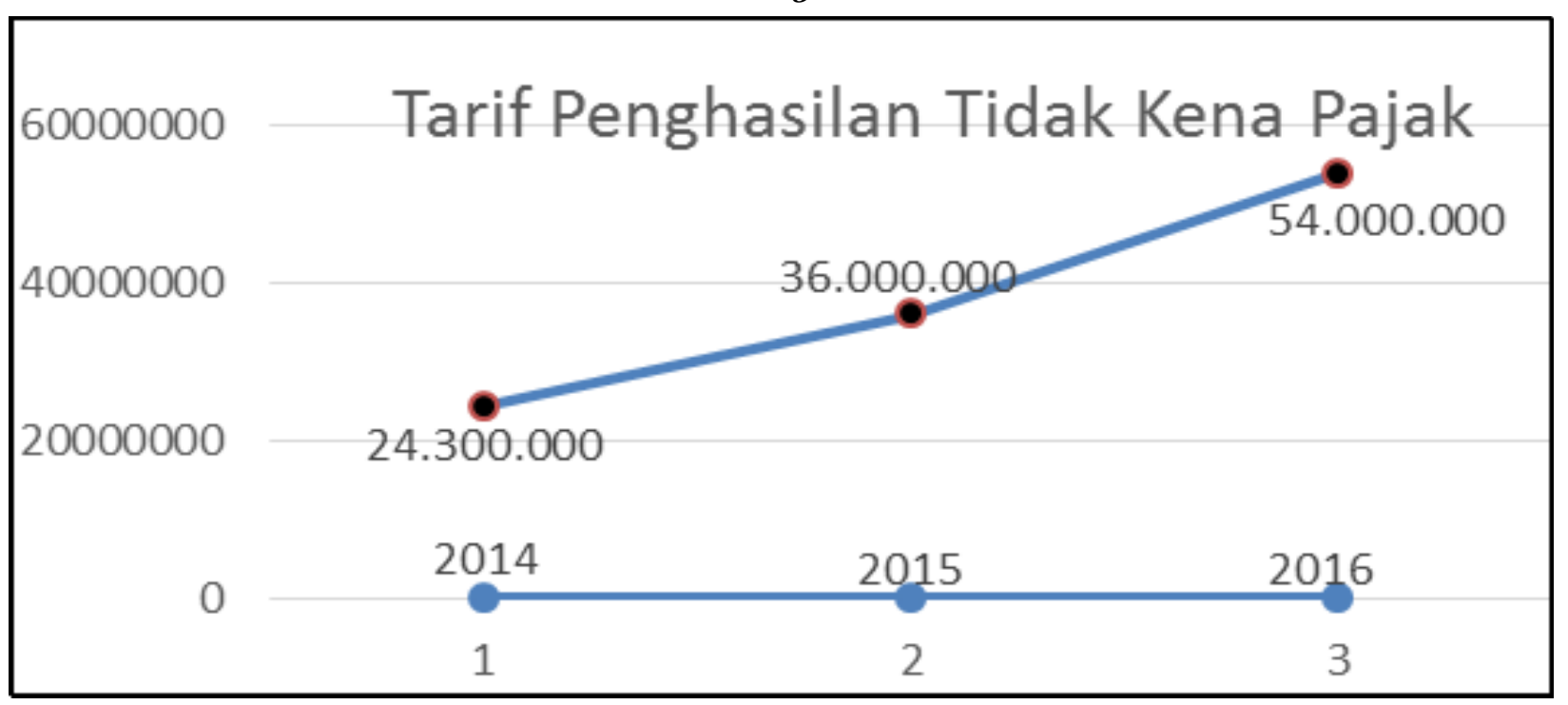

Gambar 2. Grafik kenaikan Penghasilan Tidak Kena Pajak 
Dalam gambar 3 Jumlah Wajib Pajak Efektif dan $\quad$ pada penelitian ini menggunakan data Wajib Pajak gambar 4 Realisasi Penerimaan PPh Pasal 21

PPh 21 karyawan, sebagai berikut:

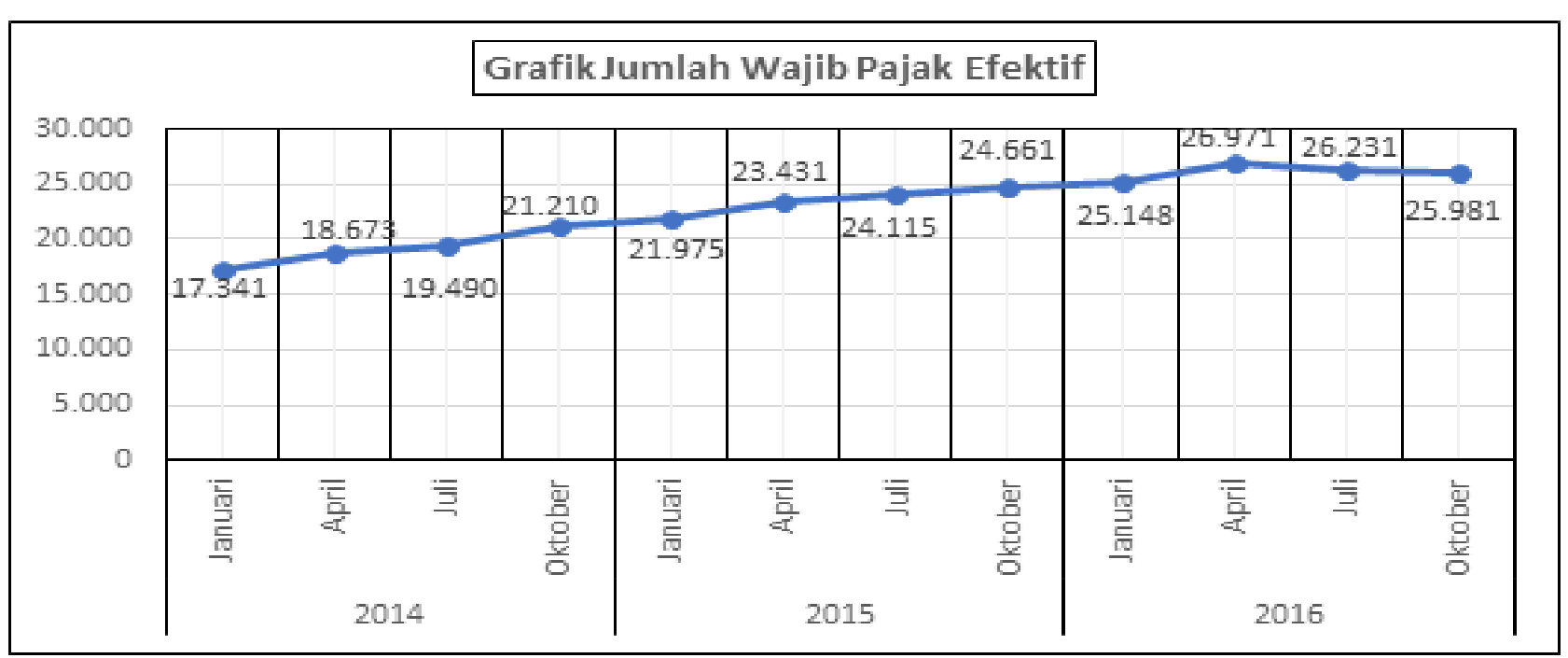

Gambar 3. Grafik Jumlah Wajib Pajak Efektif

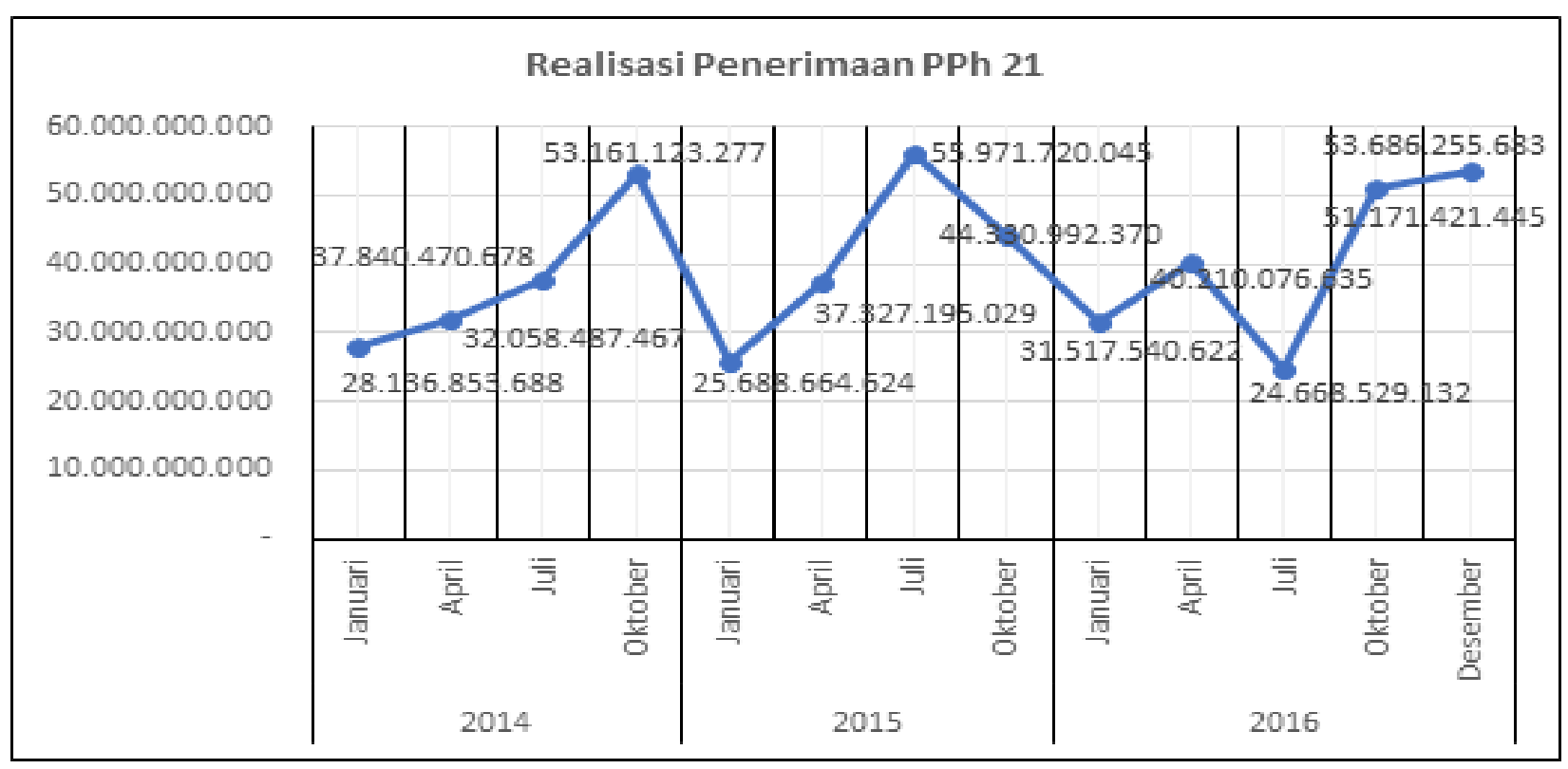

Gambar 4. Grafik Realisasi Penerimaan PPh Pasal 21

Hasil perhitungan analisis deskriptif sebagai berikut: menggunakan SPSS 20 ditampilkan pada tabel 5

Tabel 5. Statistik Deskriptif Variabel Penelitian Descriptive Statistics

\begin{tabular}{lrrrrr}
\hline & $\mathrm{N}$ & Minimum & Maxim um & Mean & Std. Deviation \\
\hline PTKP & 36 & 24300000 & 54000000 & 38100000 & 12388842,90 \\
\hline Wajib Pajak Efektif & 36 & 17341 & 27689 & 23192,72 & 3021,61 \\
\hline Penerimaan PPh 21 & 36 & 24404230466,0 & 68532749829,0 & 41368269658,38 & 11698561566,58 \\
\hline Valid N (listwise) & 36 & & & & \\
\hline
\end{tabular}

Sumber :Output SPSS yang diolah, 2018 
Jumlah sampel dalam penelitian ini sebanyak 36 yang didapati dari periode penelitian tahun 2014-2016, hasil analisis statistik deskriptif terhadap variabel $\mathrm{X}_{1}$ Penghasilan Tidak Kena Pajak menunjukkan nilai minimum sebesar Rp.24.300.000,- yang terjadi sepanjang tahun 2014 dan nilai maksimum sebesar Rp.54.000.000,- pada tahun 2016, kemudian nilai rata-rata (mean) Penghasilan Tidak Kena Pajak (PTKP) dari tahun 2014-2016 diperoleh sebesar Rp.38.100.000,- dengan standar deviasi sebesar Rp.12.388.842,90,-. Hasil analisis statistik deskriptif terhadap variabel $\mathrm{X}_{2}$ yaitu jumlah Wajib Pajak Efektif PPh Pasal 21 menunjukkan nilai minimum sebesar 17.341 Wajib Pajak pada bulan Januari tahun 2014 dan nilai maksimum sebesar 27.689 Wajib Pajak yang terjadi pada bulan Desember 2016, kemudian nilai rata-rata (mean) dari jumlah Wajib Pajak efektif sebesar 23192,722 yang diperoleh dari Januari 2014 sampai dengan Desember 2016, dengan standar deviasi sebesar 3.021,61.

Untuk hasil analisis dari variabel $\mathrm{Y}$ yaitu penerimaan $\mathrm{PPh}$ Pasal 21 pada karyawan menghasilkan nilai minimum sebesar Rp. 24.404.230.466,- yang terjadi pada bulan Juni 2016 dan nilai maksimum sebesar Rp. 68.532.749.829,pada bulan Desember 2015, kemudian nilai rata-rata (mean) dari penerimaan PPh Pasal 21 sebesar Rp. 41.368.269.658,38,- yang diperoleh dari Januari 2014 sampai dengan Desember 2016, dengan standar deviasi sebesar Rp. 11.698.561.566,58,-.

Sebelum dilakukan analisis regresis linier untuk pengujian hipotesis, maka terlebih dahulu dilakukan pengujian pengabsahan persamaan regresi asumsi klasik. Secara teoritis, model yang digunakan akan menghasilkan nilai parameter penduga yang sesuai bila memenuhi asumsi normalitas, tidak terjadi multikolonearitas, tidak terjadi heteroskidatisitas, dan tidak terjadi autokorelasi. Normalitas residual diharuskan untuk mendapatkan kesimpulan yang valid. Untuk memeriksa asumsi kenormalan, digunakan Kolmogorov-Smirnov Test, dengan kaidah keputusan jika Asym. Sig (2-tailed) lebih dari 0,05 (taraf kesalahan 5\%), maka dapat dikatakan residual model berdistribusi normal. Hasil pemeriksaan asumsi normalitas residual, berdasarkan hasil pengujian berikut nilai Asyim. Sig (2-tailed) adalah 0,904 lebih besar dari 0,05. Artinya dapat dikatakan bahwa residual model berdistribusi normal sebagai berikut :

Tabel 6. Uji Normalitas

\begin{tabular}{|c|c|c|}
\hline \multirow[b]{2}{*}{$\mathrm{N}$} & & $\begin{array}{c}\text { Unstandardized } \\
R \text { esid ual }\end{array}$ \\
\hline & & 36 \\
\hline & $M e a n$ &, 0000106 \\
\hline Norm al Param eters ${ }^{a, b}$ & $\begin{array}{l}\text { Std. } \\
\text { Deviation }\end{array}$ & 7622514215,74647200 \\
\hline & Absolute &, 095 \\
\hline Differencos & Positive & , 095 \\
\hline 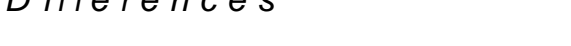 & Negative &,- 072 \\
\hline KoIm ogorov-Sm irnovZ & &, 568 \\
\hline A s ymp. Sig. (2-tailed) & &, 904 \\
\hline
\end{tabular}

a. Test distribution is Normal.

b. Calculated from data

Sumber :Output SPSS yang diolah, 2018

Untuk mendeteksi ada atau tidaknya multikolonieritas di dalam model regresi berganda dapat dilihat dari Tolerance dan Variance Inflation Factor (VIF), jika nilai tolerance di atas 0,1 dan nilai VIF di bawah
10, maka tidak terjadi masalah multikolinieritas, artinya model regresi tersebut baik (Ghozali, 2013:105). Untuk lebih jelasnya dapat dilihat pada tabel 7 sebagai berikut : 
Tabel 7. Uji Multikolinieritas

\begin{tabular}{|c|c|c|c|}
\hline \multicolumn{4}{|c|}{ Co efficients ${ }^{a}$} \\
\hline \multirow{3}{*}{ M o d e I } & & Colline & \\
\hline & & Tolerance & \\
\hline & $(C \circ n \operatorname{stan} t)$ & & \\
\hline \multirow[t]{2}{*}{1} & $\mathrm{P} T \mathrm{~T} \mathrm{P}$ &, 183 & 5,476 \\
\hline & W a jib P a jak Efektif &, 183 & 5,476 \\
\hline
\end{tabular}

Sumber :Output SPSS yang diolah, 2018

Berdasarkan tabel 7 di atas menunjukkan tidak ada satupun variabel independen yang saling berkorelasi secara statistik. Hal ini dapat dilihat dari Tolerance dan Variance Infation Factor (VIF) masing-masing variabel. Untuk nilai Tolerance masing-masing variabel di atas 0,1 dan untuk nilai VIF masing-masing variabel di bawah 10 sehingga semua variabel independent dapat dapat dinyatakan tidak terjadi masalah Multikolinieritas.

Untuk mengetahui ada tidaknya heteroskedastisitas dapat digunakan Uji Gleijser, untuk mendeteksi ada atau tidaknya heteroskedastisitas dengan melakukan uji glejser, jika nilai signifikansi $>0,05$ maka tidak terjadi heteroskedastisitas (Ghozali, 2013:143), sebagai berikut :

Tabel 8. Uji Heteroskedastisitas

\begin{tabular}{|c|c|c|c|c|c|c|}
\hline & \multicolumn{6}{|c|}{ Coefficients $^{a}$} \\
\hline & \multirow{2}{*}{ Model } & \multicolumn{2}{|c|}{ Unstandardized Coefficients } & \multirow{2}{*}{$\begin{array}{c}\text { Standardized } \\
\text { Coefficients } \\
\text { Beta }\end{array}$} & \multirow[t]{2}{*}{$\mathrm{T}$} & \multirow[t]{2}{*}{ Sig. } \\
\hline & & $\mathrm{B}$ & Std. Error & & & \\
\hline & (Constant) & $-6603866786,077$ & 8154293209,713 & &,- 810 & ,424 \\
\hline \multirow[t]{2}{*}{1} & РTKP & $-41,282$ & 129,413 &,- 122 &,- 319 & ,752 \\
\hline & WP efektif & 623264,818 & 530602,538 & 449 & 1,175 & 249 \\
\hline
\end{tabular}

\section{a. Dependent Variable: RES2}

Sumber :Output SPSS yang diolah, 2018

Tabel 8 di atas menunjukkan tidak ada satupun variabel independen yang signifikan secara statistik. Hal ini dapat terlihat dari tingkat Signifikasi untuk Penghasilan Tidak Kena pajak dan Jumlah Wajib Pajak Efektif lebih besar dari 0,05 sehingga $\mathrm{H}_{0}$ diterima atau semua variabel independent dapat dinyatakan bebas heteroskedastisitas.

Cara yang digunakan untuk mendeteksi ada atau tidaknya autokorelasi adalah dengan uji DurbinWatson (DW) yaitu dengan membandingkan nilai DW hitung dengan DW tabel. Untuk lebih jelasnya dapat dilihat pada tabel 9 sebagai berikut :

Tabel 9. Hasil Uji Autokorelasi - Durbin-Watson

Model Sum mary

\begin{tabular}{|c|c|c|c|c|c|}
\hline Model & $\mathrm{R}$ & R Square & $\begin{array}{l}\text { Adjusted } R \\
\text { Square }\end{array}$ & $\begin{array}{c}\text { Std. Error of the } \\
\text { Estimate }\end{array}$ & Durbin-Watson \\
\hline 1 &, $759^{a}$ &, 575 &, 550 & 7850101917,7403 & 1,036 \\
\hline
\end{tabular}


Berdasarkan tabel 9 hasil uji Autokorelasi Durbin Watson diatas, diketahui nilai Durbin Watson sebesar 1,036 . Nilai ini terletak antara nilai $\mathrm{dL}=1,353$ dan $\mathrm{dU}=1,587$ sehingga tidak ada kesimpulan yang pastu tentang ada atau tidaknya gejala autokorelasi dari data tersebut. Oleh karena itu, dilakukan uji autokorelasi tambahan dengan menggunakan uji Runs Test. Uji Runs Test adalah bagian dari statistik non-parametrik yang digunakan untuk melihat apakah residual terjadi secara random atau tidak. Jika antar residual tidak terdapat hubungan korelasi maka dikatakan bahwa residual adalah acak atau random dengan nilai sig > 0,05 yang berarti tidak terjadi autokorelasi. Hasil Autokorelasi dapat dilihat pada tabel 10 sebagai berikut :

Tabel 10. Hasil Uji Autokorelasi - Runs Test

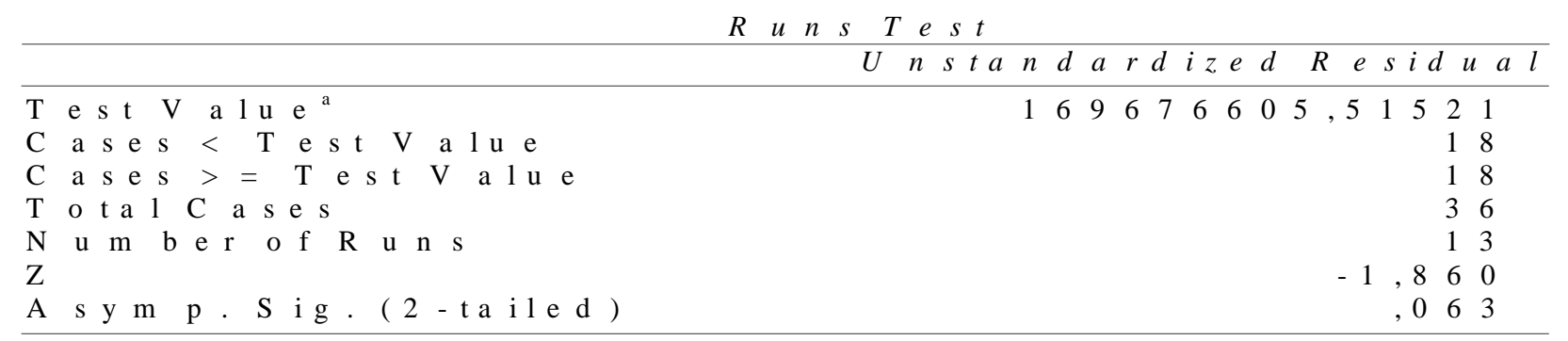

a . M e d i a $\mathrm{n}$.

Berdasarkan hasil pengolahan data pada tabel 10 dapat diketahui bahwa nilai Signifikansi 0,063 lebih dari taraf signifikansi $\quad=0,05$ atau $5 \%$ yang telah ditetapkan. Dapat disimpulkan hasil Uji Autokorelasi - Runs Test menyatakan bahwa modelregresi pada penelitian ini bebas dari:

Tabel 11. Hasil Regresi Liniear Berganda

\begin{tabular}{|c|c|c|c|c|c|c|}
\hline \multicolumn{7}{|c|}{ Coefficients ${ }^{a}$} \\
\hline \multirow[t]{2}{*}{ Model } & & Unstandardize & Coefficients & Standardized & $\mathrm{t}$ & Sig. \\
\hline & & $\mathrm{B}$ & Std. Error & Beta & & \\
\hline \multirow{3}{*}{1} & (Constant) & $-57986659122,215$ & 15792755953,823 & & $-3,672$ &, 001 \\
\hline & P T K P & $-1564,451$ & 250,639 & $-1,657$ & $-6,242$ & , 000 \\
\hline & W P E fektif & 6853896,153 & 1027639,819 & 1,770 & 6,670 &, 000 \\
\hline
\end{tabular}
Sumber: Output SPSS yang diolah, 2018

Berdasarkan output diatas bisa kita lihat hasil persamaan regresi linier berganda dalam sebuah model sebagai berikut :

\section{$\mathbf{Y}=\alpha+\beta_{1} \mathbf{X}_{1}+\beta_{2} \mathbf{X}_{2}+\mathbf{e}$, \\ Penerimaan PPh $21=\alpha_{+} \beta_{1}$ Ptkp $+\beta_{2}$ WP Efektif $+\varepsilon$}

Nilai-nilai pada output pun kemudian dimasukkan ke dalam model maka didapat persamaan regresi sebagai berikut :

Peneriman PPh $21=57.986 .659 .122,215+(-564,451)$

PTKP + 6.853.896,153 WP Efektif $+\varepsilon$

Berdasarkan persamaan diatas, dapat disimpulkan bahwa: 1) Konstanta sebesar Rp.57.986.659.122,215 menunjukkan bahwa apabila variabel independen (Penghasilan Tidak Kena Pajak/ PTKP dan jumlah Wajib Pajak Efektif) konstan atau dianggap nol, maka Penerimaan Pajak Penghasilan Pasal 21 sebesar Rp.57.986.659.122,215,-; 2) Nilaikoefisien regresi $\beta_{1}$ PTKP sebesar -1564,451

\section{Autokorelasi.}

Pengujian persamaan regresi linier berganda merupakan analisis yang mengukur pengaruh variabel bebas terhadap variabel terkait. Hasil Regresi Liniear Berganda dapat dilihat pada tabel 11 sebagai berikut: menunjukkan bahwa setiap kenaikkan penghasilan tidak kena pajak (PTKP) sebesar 1\%, maka akan diikuti oleh penurunan Penerimaan Pajak Penghasilan Pasal 21; 3) Nilai koefisien regresi $\beta_{2}$ Wajib Pajak efektif PPh Pasal 21 sebanyak 6.853.896,153 menunjukkan bahwa setiap kenaikkan jumlah Wajib Pajak Efektif sebesar 1\%, maka akan diikuti oleh kenaikkan penerimaan Pajak Penghasilan Pasal 21.

Nilai koefisien determinasi ditunjukkan dengan nilai adjusted $R$-Square, nilai ini pada intinya mengukur seberapa jauh kemampuan model dalam menerangkan variasi variabel dependen atau terikat. Selain itu, pengujian ini bertujuan untuk menguji tingkat keeratan hubungan antara variabel-variabel independen terhadap variabel dependen. Adapun hasil dari uji koefisien determinasi dari penelitian ini dapat kita lihat pada tabel 12 sebagai berikut: 
Tabel 12. Uji Koefisien Determinasi (R2)

Model $S$ u m $m$ ary

\begin{tabular}{|c|c|c|c|c|c|}
\hline Model & $\mathrm{R}$ & $R$ Square & $\begin{array}{l}\text { Adjusted } R \\
\text { Square }\end{array}$ & $\begin{array}{c}\text { Std. Error of the } \\
\text { Estim ate }\end{array}$ & $\begin{array}{l}\text { Durbin - } \\
\text { W atson }\end{array}$ \\
\hline 1 &, $759^{a}$ &, 575 &, 550 & 7850101917,7403 & 1,036 \\
\hline
\end{tabular}

Sumber: Output SPSS yang diolah, 2018

Dari hasil perhitungan didapat nilai adjusted $R$ Square sebesar 0,55. Hal tersebut menyatakan variasi variabel dependen Penerimaan Pajak Penghasilan Pasal 21 dapat dijelaskan oleh variasi variabel independen (Penghasilan Tidak Kena Pajak dan Jumlah Wajib Pajak Efektif) sebesar 55\%, sedangkan sisanya yaitu 45\% dijelaskan oleh faktor lain atau variabel lain yang tidak tercakup dalam model penelitian ini.

Adapun hasil dari uji statistik F dalam penelitian ini dapat dilihat pada tabel 13 sebagai berikut:

Tabel 13. Hasil Uji F

ANOVA $^{a}$

\begin{tabular}{llrrrrr}
\hline Model & & Sum of Squares & df & Mean Square & F & Sig. \\
\hline \multirow{2}{*}{1} & Regression & $2,756 \mathrm{E}+21$ & 2 & $1,378 \mathrm{E}+21$ & 22,364 &, $000^{\mathrm{D}}$ \\
& Residual & $2,034 \mathrm{E}+21$ & 33 & $6,162 \mathrm{E}+19$ & & \\
\hline & Total & $4,790 \mathrm{E}+21$ & 35 & & & \\
\hline
\end{tabular}

a. Dependent Variable: Penerimaan PPh 21 Karyawan

b. Predictors: (Constant), W P efektif, PTKP

Sumber: Output SPSS yang diolah, 2018

$\mathrm{F}$ tabel $=(\mathrm{k} ; \mathrm{n}-\mathrm{k})$

$$
\begin{aligned}
& =(2 ; 36-2) \\
& =(2 ; 34) \rightarrow 3,29
\end{aligned}
$$

Dari uji ANOVA didapat nilai hitung sebesar 22,364 dengan signifikansi 0,000 dan nilai $\mathrm{F}$ tabel dengan menggunakan derajat kepercayaan 95\% atau á = 0,05 sebesar 3,29, karena nilai $F_{\text {hitung }}>F_{\text {tabel }}$ dan nilai signifikansi lebih kecil dari 0,05 maka $\mathrm{H}_{0}$ ditolak atau terdapat pengaruh yang cukup signifikan secara simultan atau antara variabel independen terhadap variabel dependen, atau dengan kata lain variabel Penghasilan Tidak Kena Pajak dan Jumlah Wajib Pajak Efektif berpengaruh terhadap penerimaan Pajak Penghasilan Pasal 21. Hasil Uji t dapat dilihat pada table 14 sebagai beikut:

Tabel 14. Hasil Uji t

\begin{tabular}{|c|c|c|c|c|c|c|}
\hline \multirow[t]{2}{*}{ Model } & & \multicolumn{2}{|c|}{ Unstandardized Coefficients } & \multirow{2}{*}{$\begin{array}{c}\text { Standardized } \\
\text { Coefficients } \\
\text { Beta }\end{array}$} & \multirow[t]{2}{*}{$\mathrm{t}$} & \multirow[t]{2}{*}{ Sig. } \\
\hline & & B & Std. Error & & & \\
\hline & (Constant) & $-57986659122,215$ & 15792755953,823 & & $-3,672$ & ,001 \\
\hline 1 & $\begin{array}{l}\text { PTKP } \\
\text { WP Efektif }\end{array}$ & $\begin{array}{r}-1564,451 \\
6853896,153 \\
\end{array}$ & $\begin{array}{r}250,639 \\
1027639,819 \\
\end{array}$ & $\begin{array}{r}-1,657 \\
1,770\end{array}$ & $\begin{array}{r}-6,242 \\
6,670\end{array}$ & $\begin{array}{l}, 000 \\
, 000\end{array}$ \\
\hline
\end{tabular}

Coefficients $^{a}$

a. Dependent Variable: Penerimaan PPh 21 Karyawan

Sumber: Output SPSS yang diolah, 2018

$$
\begin{aligned}
\mathrm{T} \text { tabel } & =(\mathrm{a} / 2 ; \mathrm{n}-\mathrm{k}-1) \\
& =(0,05 / 2 ; 2-36-1) \\
& =(0,025 ; 33) \rightarrow 2,034
\end{aligned}
$$

\section{Hipotesis 1}

Diketahui nilai konstanta sebesar 57.986.659.122,125 ( ). Variabel ukuran Penghasilan Tidak Kena Pajak (PTKP) memiliki arah koefisien negatif -1564,451 ( $\left.\hat{a}_{1}\right)$ dengan signifikansi 0,000 dan memiliki $\mathrm{T}_{\text {hitung sebesar }-6,242 \text { serta }} \mathrm{T}_{\text {tabel }}$ sebesar 2,034, yang berarti $\mathrm{T}_{\text {hitung }}>\mathrm{T}_{\text {tabel }}$. Hasil tersebut menunjukkan bahwa ukuran Penghasilan Tidak Kena Pajak (PTKP) berpengaruh negatif terhadap penerimaan PPh Pasal 21 pada KPP Pratama Serang tahun 2014-2016. 


\section{Hipotesis 2}

Diketahui nilai konstanta sebesar 57.986.659.122,215 (á). Variabel ukuran Jumlah Wajib Pajak Efektif memiliki arah koefisien positif 6.853.896,153 (ân $)$ dengan signifikansi 0,000 dan memiliki $\mathrm{T}_{\text {hitung }}$ sebesar 6,670 serta $\mathrm{T}_{\text {tabel }}$ sebesar 2,034, yang berarti $\mathrm{T}_{\text {hitung }}>\mathrm{T}_{\text {tabel }}$. Hasil tersebut menunjukkan bahwa ukuran jumlah Wajib Pajak Efektif berpengaruh positif terhadap Penerimaan PPh Pasal 21 pada KPP Pratama Serang tahun 2014-2016.

Uji hipotesis pertama dalam penelitian ini menyatakan bahwa Penghasilan Tidak Kena Pajak (PTKP) berpengaruh terhadap Penerimaan Pajak Penghasilan (PPh) Pasal 21. Hasil pengujian yang dilakukan menggunakan metode analisis regresi berganda dengan penerimaan PPh Pasal 21 software SPSS versi 20 menunjukan bahwa nilai hipotesis pertama diterima. Begitu juga dengan nilai signifikasi memiliki nilai 0,000 yang lebih kecil dari 0,05 sehingga hipotesis dinyatakan signifikan. Selain itu penelitian ini menemukan bahwa nilai beta -1564,451 sehingga penelitian ini berpengaruh negatif. Berdasarkan hasil tersebut dapat disimpulkan bahwa Penghasilan Tidak Kena Pajak (PTKP) berpengaruh negatif tehadap tarif PPh Pasal 21, hal ini menjelaskan bahwa semakin tinggi tarif Penghasilan Tidak Kena Pajak (PTKP) akan menurunkan penerimaan PPh Pasal 21 di KPP Pratama Serang.

Perubahan tarif Penghasilan Tidak Kena Pajak (PTKP) yang telah disahkan melalaui Peraturan Menteri Keuangan Nomor 162/PMK.011/2012, kemudian Nomor 122/PMK.010/2015 dan 101/ PMK.010/2016 dapat mempengaruhi penerimaan Pajak Penghasilan Pasal 21. Seperti halnya yang terjadi pada KPP Pratama Serang, untuk tahun 2014 realisasi penerimaan Pajak Penghasilan 21 karyawan sebesar Rp.485.196.033.250,- kemudian pada tahun 2015 penerimaan meningkat menjadi Rp.530.790.261.367,- namun untuk tahun 2016 realisasi penerimaan Pajak Penghasilan Pasal 21 pada KPP Pratama Serang turun menjadi Rp.473.271.413.085,-. Hasil penelitian ini sesuai dengan pemikiran secara sistematis atau logika bahwa semakin besar perubahan tarif Penghasilan Tidak Kena Pajak (PTKP) maka semakin kecil Penerimaan Pajak Penghasilan Pasal 21 yang diperoleh.

Menurut Resmi,Siti (2013:96) Penghasilan Tidak Kena Pajak (PTKP) merupakan jumlah penghasilan tertentu yang tidak kena pajak. Untuk menghitung besarnya Penghasilan Kena Pajak (PKP) Wajib Pajak dalam negeri, penghasilan netonya dikurangi dengan jumlah Penghasilan Tidak Kena Pajak. Hasil penelitian ini selaras dengan teori dari Etty Musyaroh (2012:42) yaitu kenaikan Penghasilan Tidak Kena Pajak (PTKP) mempengaruhi penerimaan pajak penghasilan karena dengan kenaikan besaran PTKP mempersulit perolehan pajak penghasilan, dan penelitian terdahulu yang telah dilakukan oleh Nuritomo (2011) dan Sitti Juariah (2017) yang menghasilkan bahwa peningkatan PTKP dapat menyebabkan menurunya penerimaan Pajak Penghasilan Pasal 21. Sedangkan penelitian ini berlainan dengan penelitian yang dilakukan oleh Rahmawati (2013) yang menyatakan kenaikan Penghasilan Tidak Kena Pajak (PTKP) justru menambah penerimaan negara dari PPh Pasal 21.

Penelitian yang dilakukan oleh Nuritomo (2011) menyatakan bahwa perubahan peraturan Penghasilan Tidak Kena Pajak(PTKP) dapat menimbulkan potensial loss pada pendapatan pajak PPh Pasal 21 yang diterima oleh KPP Yogyakarta Satu, maka dari itu perubahan PTKP ini memberikan pengaruh yang besar terhadap Penerimaan Pajak Penghasilan Pasal 21. Kemudian senada dengan penelitian dari Sitti Juariah (2017) yang dilakukan pada 10 KPP yang terdaftar pada Kanwil DJP Jawa Barat I menyatakan bahwa penerimaan pajak penghasilan Orang Pribadi tidak mencapai target. Menurut Hendrian selaku Kabid Dukungan Teknis dan Konsultasi Kanwil DJP Jabar I (2015), dari tahun ke tahun selama lima tahun terakhir terjadi fluktuasi realisasi penerimaan pajak dan tidak pernah mencapai target realisasi $100 \%$, pada 2011 pajak terealisasi 89\%, pada 2012 penerimaan pajak terealisasi 97\%, pada 2013 penerimaan pajak terealisasi 94\%, kemudian 2014 sebesar 79\%, dan pada tahun 2015 sekitar 84,13\% dari target yang ditetapkan.

Uji hipotesis kedua dalam penelitian ini menyatakan bahwa Jumlah Wajib Pajak Efektif berpengaruh terhadap Penerimaan Pajak Penghasilan (PPh) Pasal 21. Hasil pengujian yang dilakukan menggunakan metode analisis regresi berganda dengan penerimaan PPh Pasal 21 software SPSS versi 20 menunjukan bahwa nilai hipotesis kedua diterima. Begitu juga dengan nilai signifikasi memiliki nilai 0,000 yang lebih kecil dari 0,05 sehingga hipotesis dinyatakan signifikan. Selain itu penelitian ini menemukan bahwa nilai beta 6,670 sehingga penelitian ini berpengaruh positif. Berdasarkan hasil tersebut dapat disimpulkan bahwa Jumlah Wajib Pajak Efektif berpengaruh positif tehadap penerimaan PPh Pasal 21, hal ini menjelaskan bahwa semakin banyak jumlah Wajib Pajak Efektif maka akan menaikan penerimaan PPh Pasal 21 di KPP Pratama 
Serang.

Wajib Pajak sangatlah memegang peranan yang sangat penting bagi kelancaran sistem dan peraturan perundang-undangan perpajakan. Berdasarkan Pasal 1 Ayat 2 Undang-Undang No.28 Tahun 2007 tentang Ketentuan Umum dan Tata Cara Perpajakan bahwa yang dimaksud dengan Wajib Pajak (tax payer) yaitu Orang Pribadi atau badan yang menurut ketentuan peraturan perundang-undangan perpajakan ditentukan untuk melakukan kewajiban perpajakan, termasuk pemungut pajak atau pemotong pajak tertentu. Dengan demikian Wajib Pajak dituntut untuk melakukan kewajiban perpajakan, termasuk pemungut pajak atau pemotong pajak tertentu. Oleh karena itu pemerintah terus mengupayakan agar Wajib Pajak memahami sepenuhnya kewajibannya terhadap negara dan mau melaksanakannya kewajiban perpajakannya. Saat ini banyak Wajib Pajak yang terdaftar yang tidak memenuhi kewajiban perpajakannya. Oleh karena itu ada beberapa istilah seperti Wajib Pajak Efektif dan Wajib Pajak Non Efektif.

Berdasarkan Surat Edaran Dirjen Pajak Nomor SE-26/PJ.2/1988 pengertian Wajib Pajak Efektif itu sendiri yaitu Wajib Pajak yang memenuhi kewajiban perpajakannya berupa memenuhi kewajiban menyampaikan Surat Pemberitahuan (SPT) Masa dan atau Surat Pemberitahuan (SPT) Tahunan sebagaimana mestinya, atau dengan singkat kita dapat mengatakan Wajib Pajak efektif yaitu Wajib Pajak yang masih memenuhi kewajiban perpajakanya. Dalam penelitian ini Wajib Pajak Efektif yang dimaksud yaitu Wajib Pajak Efektif PPh Pasal 21 yang berstatus karyawan.

Dari hasil Uji Statistik yang telah dilakukan, variabel Wajib Pajak Efektif PPh Pasal 21 karyawan di KPP Pratama Serang tahun 2014-2016 menghasilkan jumlah yang meningkat. Bisa kita lihat jumlah Wajib Pajak Efektif PPh Pasal 21 untuk tahun 2014 sebesar 234.533 Wajib Pajak, tahun 2015 jumlahnya meningkat menjadi 284.741 Wajib Pajak, dan 2016 sebesar 315.664 Wajib Pajak. Hasil penelitian ini sesuai dengan teori yang dikemukakan oleh Rochmat Soemitro yang dikutip oleh Rahayu,Siti (2010 : 90) yang menyatakan bahwa untuk menunjang penerimaan negara dalam bidang perpajakan dapat ditempuh salah satunya dengan cara perluasan dan peningkatan Wajib Pajak.

Hasil peneitian ini selaras dengan penelitian yang dilakukan oleh Amina Lainutu (2013) yang dilakukan pada KPP Pratama Manado, dan penelitian dari Andiyanto dkk (2013) yang dilakukan pada KPP Pratama Banyuwangi dan KPP Pratama Malang
Selatan menyatakan jumlah Wajib Pajak Orang Pribadi berpengaruh positif terhadap Penerimaan Pajak Penghasilan Pasal 21. Kemudian penelitian yang dilakukan Wati dan Heru (2014) pada KPP yang berada di wilayah lingkungan DJP Jawa Barat I, menyatakan bahwa jumlah Wajib Pajak Efektif berpengaruh positif terhadap penerimaan Pajak Penghasilan Pasal 21.

\section{SIMPULAN DAN SARAN}

\section{Simpulan}

Adapun simpulan yang dapat diambil dari penelitian ini adalah: 1) Hasil Uji Analisis Regresi menunjukkan bahwa secara statistik terbukti Penghasilan Tidak Kena Pajak berpengaruh terhadap penerimaan Pajak Penghasilan (PPh) Pasal 21 pada KPP Pratama Serang periode 2014-2016, serta menghasilkan angka t hitung dan beta yang menunjukan arah negatif. Oleh karena itu, ketika peraturan tentang tarif Penghasilan Tidak Kena Pajak (PTKP) mengalami kenaikan maka penerimaan Pajak Penghasilan ( $\mathrm{PPh}$ ) Pasal 21 pada KPP Pratama Serang akan mengalami penurunan; 2) Hasil Uji Analisis Regresi menunjukkan bahwa secara statistik terbukti bahwa jumlah Wajib Pajak Efektif PPh Pasal 21 berpengaruh terhadap penerimaan Pajak Penghasilan (PPh) Pasal 21 di KPP Pratama Serang periode 2014-2016, serta menghasilkan angka thiitung dan beta yang menunjukan arah positif. Oleh karena itu, pada saat terjadi petumbuhan jumlah Wajib Pajak Efektif maka penerimaan Pajak Penghasilan Pasal 21 di KPP Pratama Serang akan mengalami kenaikan.

\section{Saran}

Berdasarkan hasil dari penelitian, saran yang dapat diberikan sabagai berikut:

Bagi instansi, 1) Untuk KPP Pratama Serang, diperbanyak kembali penyuluhan mengenai perubahan-perubahan peraturan yang telah disahkan oleh pemerintah khususnya untuk penelitian ini terkait dengan kenaikan Penghasilan Tidak Kena Pajak (PTKP) dan upaya KPP Pratama Serang agar tetap meningkatkan jumlah Wajib Pajak efektif, karena dengan bertambahnya jumlah Wajib Pajak efektif terutama untuk Wajib Pajak yang berstatus membayar pajak atau memiliki penghasilan diatas PTKP akan memberikan dampak positif terhadap penerimaan Pajak Penghasilan Pasal 21; 2) Untuk pemeritah, agar melakukan pertimbangan yang sebenar benarnya ketika akan melakukan kembali perubahan tarif Penghasilan Tidak Kena Pajak 
(PTKP) karena ini akan berdampak pada pendapatan negara untuk kedepanya.

Bagi peneliti selanjutnya: 1) Untuk penelitian selanjutnya dapat menambahkan ruang lingkup yang dapat dijadikan sebagai objek penelitian. Hal ini dapat dilakukan agar peneliti memiliki berbagai macam hasil penelitian untuk dibandingkan satu sama lain dan tidak berpatokan dalam satu objek atau satu tempat saja; 2) Peneliti selanjutnya diharapkan dapat memperluas atau memperbanyak jangkauan penelitian, yaitu dengan menggunakan variable yang lebih banyak, agar hasil penelitian dapat di generalisasikan.

\section{DAFTAR PUSTAKA}

Aisyah. 2013. Pengaruh Jumlah Wajib Efektif Terhadap Penerimaan Pajak Pada Kantor Pelayanan Pajak Pratama Tanjungpinang Periode 2009-2012. Jurnal Program Studi Akuntansi Fakultas Ekonomi Universitas Maritim Raja Ali Haji (UMRAH).

Andiyanto, Susilo, dan Kurniawan.2014.Analisis Perubahan Penghasilan Tidak Kena Pajak (PTKP) Terhadap Tingkat Pertumbuhan Jumlah Wajib Pajak Orang Pribadi Dan Penerimaan Pajak Penghasilan. Jurnal Universitas Brawijaya.

Apriliawati1, Yeti dan Setiawan.2017. Analisa Kenaikan Penghasilan Tidak Kena Pajak Pada Penerimaan Pajak Penghasilan. Jurnal Ecodemica, Vol. 1 No. 1 April.

Ari Akbar Irawan.2016. Pengaruh Perubahan Penghasilan Tidak Kena Pajak Dan Tarif Pajak Penghasilan Orang Pribadi Terhadap Penerimaan Pajak Penghasilan. Universitas Komputer Indonesia.

Astuti,Rusdianto.2013.Pengaruh Jumlah Wajib Pajak Efektif Dan Pemeriksaan Pajak Terhadap Penerimaan Pajak Penghasilan Pasal 21. Universitas Komputer Indonesia.

Farnika,Novita.2013. Analisis Penerimaan Pajak Pada Kantor Wilayah Direktorat Jendral Pajak Wajib Pajak Besar Setelah Pemberlakuan Kenikan Penghasilan Tidak Kena Pajak.Universitas Negeri Surabaya.

Fermana, Mulya. 2014. Pengaruh Kepatuhan Wajib Pajak dan Jumlah Wajib Pajak Efektif terhadap Penerimaan Pajak. Jurnal Universitas Komputer Indonesia

Ghozali, Imam. 2013. Aplikasi Analisis Mutivariate dengan program IBM SPSS 20. Semarang: Universitas Diponogoro.

Harian Kontan pada tanggal 26 Juli 2016 dalam ortax.org diakses pada tanggal 15 September 2017.

Juariah, Sitti. 2017. Pengaruh Jumlah Wajib Pajak Orang Pribadi dan Batas Kenaikan Penghasilan Tidak Kena Pajak Terhada Penerimaan Pajak Penghasilan Orang Pribadi. Jurnal Universitas Komputer Indonesia.

Lainutu, Amina.2013.Pengaruh Jumlah Wajib Pajak PPh 21 Terhadap Penerimaan PPh 21 Pada KPP Pratama Manado,ISSN 2303-1174.
Malia,Evi dan Qoyyimah. 2016. Analisis Kenaikan PTKP Sebagai Upaya Peningkatan Pertumbuhan Wajib Pajak Dan Penerimaan Pajak Penghasilan Di KPP Pratama Pamekasan. Jurnal "PERFORMANCE” Bisnis \& Akuntansi Volume VI, No.2, September 2016

Michel Salim, Lily Syafitri.2008. Analisis Pengaruh Kenaikan PTKP Terhadap Penerimaan Pajak Penghasilan Pada Kantor Pelayanan Pajak Pratama Palembang Hilir Barat. Jurnal Perpajakan.

Mardiasmo, 2013. Perpajakan. Yogyakarta : Andi Newsmedia.co.id/kesedaran/masyarakat/masih/ rendah diakses pada 10 Desember 2017

Nuritomo.2011. Pengaruh Peningkatan Penghasilan Tidak Kena Pajak Terhadap Penerimaan Pajak Studi Pada KPP Yogyakarta Satu.Jurnal Ilmiah Akuntansi Bisnis Vol.6 No.1 Januari.

Rahmawati.2013. Perubahan Tingkat Inflasi Dan Pendapatan Tidak Kena Pajak Terhadap Penerimaan Negara. Jurnal Signifikan Vol. 2 No. 1 April.

Rahawati,Lusy.2016. Pengaruh Jumlah Wajib Pajak Efektif Dan Penagihan Pajak Dengan Surat Paksa Terhadap Penerimaan Pajak.Universitas Komputer.

Rahayu,Siti 2010. Perpajakan Indonesia: Konsep Dan Aspek Formal. Jakarta : Graha Ilmu

Resmi,Siti. 2013. Perpajakan Teori dan Kasus. Jakarta. Salemba Empat

Ridzky, Firmandha Pradityo. 2016. Pengaruh Jumlah Wajib Pajak dan Self Assesment System Terhadap Penerimaan Pajak Penghasilan Orang Pribadi. Jurnal Universitas Komputer Indonesia.

Suandy,Erly. 2016. Hukum Pajak, Edisi tujuh. Jakarta: Penerbit Salemba Empat.

Sumarsan,Thomas. 2010. Perpajakan Indonesia Pedoman Perpajakan yang Lengkap Berdasarkan UU Terbaru. Jakarta. Indeks.

Suparmono, dan Damayati Theresia Woro, 2010. Perpajakan Indonesia Mekanisme dan Perhitungan. Yogyakarta: Andi.

Surat Edaran Direktur Jendral Pajak Nomer SE-26/PJ.2/ 1988 Tentang Kriteria Wajib Pajak Efektif dan Wajib Pajak Non Efektif

Surat Edaran Direktur Jendral Pajak Nomer SE-89/PJ/2009 Tentang Tata Cara Penanganan Wajib Pajak Non Efektif

Timbul H. Simanjuntak dan Imam Mukhlis. 2012. Dimensi Perpajakan dalam Pembangunan Ekonomi. Jakarta: Raih asa Sukses.

Undang-Undang Nomor 36 tahun 2008 tentang Pajak Penghasilan

Sugiyono. 2014. Metode Penelitian Kuantitatif, Kualitatif, dan R\&D. Bandung: Alfabeta

Peraturan Menteri Keuangan PMK Republik Indonesia Nomor 103/pmk.011/2012 tentang Penyesuaian Besarnya Penghasilan Tidak Kena Pajak. 
Peraturan Menteri Keuangan PMK Republik Indonesia Nomor 122/pmk.010/2015 tentang Penyesuaian Besarnya Penghasilan tidak Kena Pajak.

Peraturan Menteri Keuangan PMK Republik Indonesia Nomor 101/pmk.010/2016 tentang Penyesuaian Besarnya Penghasilan Tidak Kena Pajak.

Website: http://www.online-pajak.com.id/ptkp-terbaru diakses pada tanggal 10 mei 2017 http://www.pemeriksaan.com diakses pada tanggal 11 Mei 2017

http://www.ortax.org diakses pada tanggal 15 juli 2017 http://banten.bps.go.id diakses pada 30 november 2017 http://www.kemenkeu.go.id/Berita/mulai-januari-2016ptkp-naik-jadi-rp54-juta-tahun diakses pada tanggal 10 Mei 2017

http://www.pajakbro.com/2016/10/ptkp-tahun-2001hingga-2016-lengkap diakses pada tanggal 10 Mei 2017 http://www.disnakertas.bantenprov.go.id diakses pada tanggal 30 Maret 2018 